\title{
PALB2 Biallelic Inactivation
}

National Cancer Institute

\section{Source}

National Cancer Institute. PALB2 Biallelic Inactivation. NCI Thesaurus. Code C150582.

The presence of mutations in both alleles of the PALB2 gene that either lead to loss of expression of the PALB2 protein or result in the translation of an inactive PALB2 protein. 